\title{
A POST-MORTEM STUDY OF THE VISCO-ELASTIC PROPERTIES OF NORMAL LUNGS
}

\author{
BY \\ M. B. McILROY AND R. V. CHRISTIE \\ From the Medical Professorial Unit, St. Bartholomew's Hospital, London
}

(RECEIVED FOR PUBLICATION OCTOBER 6, 1952)

It has been shown above (McIlroy, 1952) that in certain circumstances lungs removed up to 72 hours after death show a predictable response to inflation in a plethysmograph. This paper is concerned with the study of this predictable response in isolated lungs ventilated in a manner comparable to that occurring in life. The conditions of these experiments resemble those in which the intrapleural pressure and tidal air are measured simultaneously in life, the plethysmograph pressure representing the intrapleural pressure and the resultant volume change the tidal air.

\section{MeTHODS}

The methods used have been described in detail in the previous paper. The lungs were removed with the pleura intact and suspended in the plethysmograph. After inflation to open up collapsed alveoli and restore the lung volume to that found in life, the lungs were ventilated by means of the hand pump. The pressure in the plethysmograph and tidal air were recorded simultaneously on a kymograph drum.

\section{RESUlts}

When the lungs were ventilated by the hand pump at a regular respiration rate of 15 per minute the tidal air produced was usually about $300 \mathrm{ml}$. for a pressure swing of $5 \mathrm{~cm} . \mathrm{H}_{2} \mathrm{O}$ at a level of -5 $\mathrm{cm}$. $\mathrm{H}_{2} \mathrm{O}$. A typical tracing is shown in Fig. 1, from which it can be seen that the tidal air and respiratory level remained constant.

If the lungs were ventilated at.different rates the volume of the tidal air varied inversely with the respiratory rate. A typical tracing is seen in Fig. 2 , in which with slower breathing the tidal air was larger. This variation in the tidal air with different rates of breathing was due to delay in the response of the lungs to a change in pressure. An arbitrary measure of this delay was obtained by comparing the tidal airs produced at two widely differing rates. The lungs were ventilated with a constant pressure swing of $5.5 \mathrm{~cm} . \mathrm{H}_{2} \mathrm{O}$ at the arbitrary rates of 3 and 15 per minute and the tidal air measured in each case. The expression

$$
\frac{\text { Tidal air at } 3 / \mathrm{min} \text {. }}{\text { Tidal air at } 15 / \mathrm{min} \text {. }}
$$

has been used as a measure of the response time and has been called the "index of viscous resistance". The index of viscous resistance was measured at different times after death in rabbits and dogs, and the results shown in Table I indicate that this index remains relatively constant after death.

TABLE I

INDEX OF VISCOUS RESISTANCE IN NORMAL ANIMAL LUNGS MEASURED AT JNTERVALS AFTER DEATH

\begin{tabular}{|c|c|c|c|c|}
\hline \multicolumn{3}{|c|}{ Animal } & $\begin{array}{c}\text { Time } \\
\text { after Death }\end{array}$ & $\begin{array}{l}\text { Index of } \\
\text { Viscous Resistance }\end{array}$ \\
\hline Dog & $\cdots$ & $\cdots$ & $\begin{array}{l}50 \text { minutes } \\
7 \text { hours } \\
24 \text {," } \\
30 \text { ", } \\
50 \text {," }\end{array}$ & $\begin{array}{l}1 \cdot 1 \\
1.07 \\
1.09 \\
1 \cdot 12 \\
1 \cdot 16\end{array}$ \\
\hline Dog & . & . & $\begin{array}{l}40 \text { minutes } \\
7 \text { hours } \\
26 \text {, , }\end{array}$ & $\begin{array}{l}1 \cdot 15 \\
1 \cdot 08 \\
1 \cdot 23\end{array}$ \\
\hline Rabbit & . & $\cdots$ & $\begin{array}{l}20 \text { minutes } \\
1 \frac{1}{2} \text { hours } \\
33 \text { ", } \\
19 \quad, \\
23 \quad \text { ", }\end{array}$ & $\begin{array}{l}1 \cdot 19 \\
1 \cdot 33 \\
1 \cdot 11 \\
1 \cdot 26 \\
1 \cdot 09\end{array}$ \\
\hline Rabbit & $\cdots$ & $\ldots$ & $\begin{array}{l}20 \text { minutes } \\
1 \frac{1}{2} \text { hours } \\
3 \text {, } \\
8 \quad, \\
19 \quad, \\
24 \text { ", }\end{array}$ & $\begin{array}{l}1 \cdot 25 \\
1 \cdot 20 \\
1 \cdot 13 \\
1 \cdot 33 \\
1 \cdot 15 \\
1 \cdot 28\end{array}$ \\
\hline
\end{tabular}

The index of viscous resistance was measured in 20 normal human lungs removed at necropsy between 12 and 72 hours after death and also in the lungs of eight dogs. The index was measured both at an arbitrary plethysmograph pressure level of $-4 \mathrm{~cm} . \mathrm{H}_{2} \mathrm{O}$ and at the corrected level for each case as judged from the pressure generated 


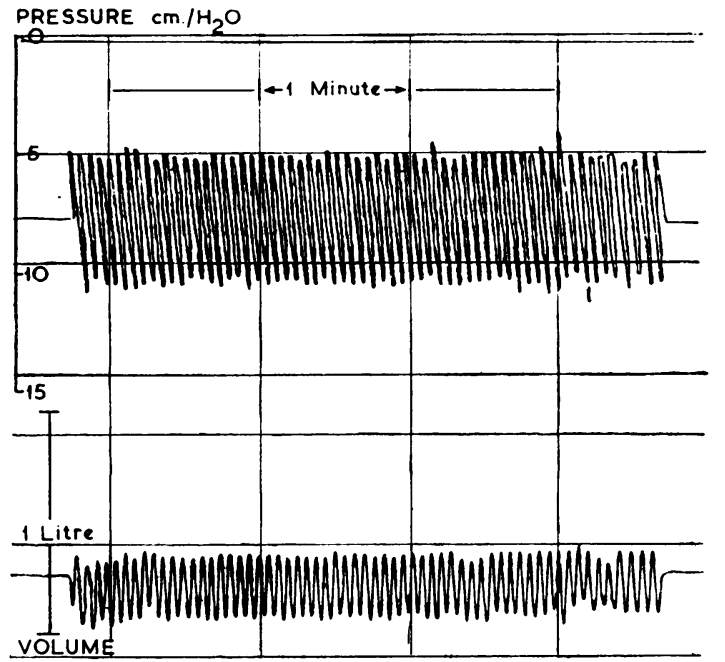

Fig. 1.-The response of normal lungs to ventilation in a plethysmograph. Upper tracing represents plethysmograph pressure and lower tracing volume of air passing in and out of the lungs which remains constant.

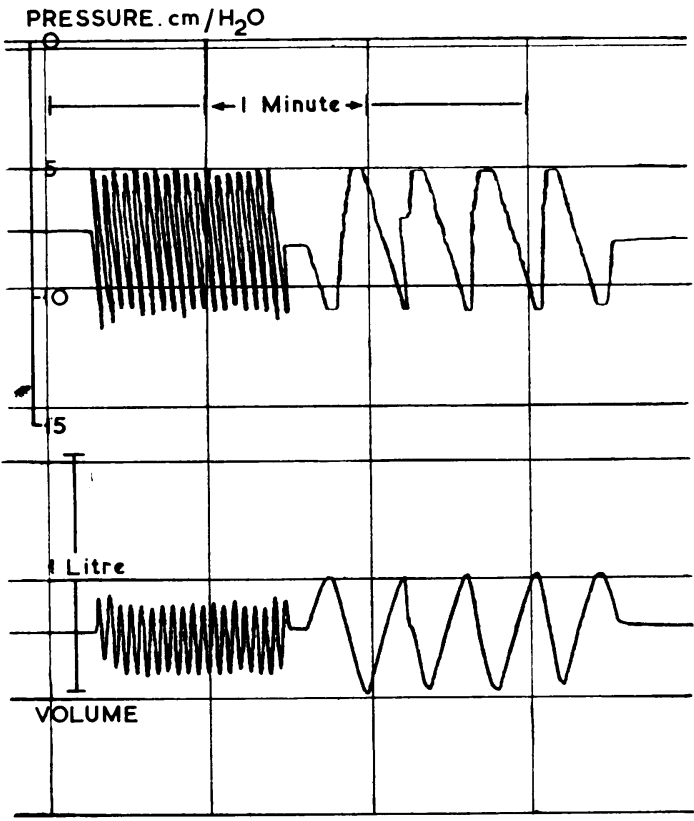

FIG. 2.-Tracing similar to Fig. 1, showing variation in volume change produced by constant pressure swing at different respiratory rates.

within the obstructed trachea on opening the thorax. Results are shown in Table II, and in Fig. 3 the index of viscous resistance at both levels has been plotted against age. From this graph it can be seen that the index of viscous resistance gradually increased with age, and that there was little difference between the results at the arbitrary leveg of $-4 \mathrm{~cm} . \mathrm{H}_{2} \mathrm{O}$ and at the corrected level $(\mathrm{r}=0.68$. and 0.62 respectively).

It has been shown by Bayliss and Robertsor (1939) and Dean and Visscher (1941) that the्छ viscous resistance to ventilation in animal lungscan be separated by the use of hydrogen into an air resistance produced in the bronchial tree and $\overrightarrow{\omega_{0}}$ tissue resistance in the lungs themselves. The indes of viscous resistance, being a measure of the speec of response of the lungs to a change in pressure,

TABLE II

INDEX OF VISCOUS RESISTANCE IN NORMAL HUMAN AND ANIMAL LUNGS

\begin{tabular}{|c|c|c|c|c|c|c|}
\hline \multirow{2}{*}{$\begin{array}{l}\text { Time } \\
\text { After } \\
\text { Death } \\
\text { (Hrs.) }\end{array}$} & \multirow{2}{*}{ 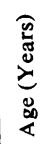 } & \multirow{2}{*}{$\begin{array}{c}\text { Intra- } \\
\text { tracheal } \\
\text { Pressure } \\
(\mathrm{cm} . \\
\left.\mathrm{H}_{2} \mathrm{O}\right)\end{array}$} & \multirow{2}{*}{$\begin{array}{l}\text { Lung } \\
\text { Volume } \\
\text { after } \\
\text { Infla- } \\
\text { tion } \\
\text { (ml.) }\end{array}$} & \multicolumn{2}{|c|}{$\begin{array}{l}\text { Index of Viscous } \\
\text { Resistance at }\end{array}$} & \multirow{2}{*}{$\begin{array}{c}\text { Diagnosis and } \\
\text { Remarks }\end{array}$} \\
\hline & & & & $\begin{array}{c}\text { Cor- } \\
\text { rected } \\
\text { Level }\end{array}$ & $\begin{array}{c}-4 \mathrm{~cm} \\
\mathrm{H}_{2} \mathrm{O}\end{array}$ & \\
\hline 12 & 78 & $4 \cdot 2$ & 3,960 & $1 \cdot 76$ & $1 \cdot 76$ & $\begin{array}{c}\text { Coronary throm } \\
\text { bosis }\end{array}$ \\
\hline $\begin{array}{l}13 \\
14 \\
16\end{array}$ & $\begin{array}{l}61 \\
28 \\
49\end{array}$ & $\begin{array}{l}3 \cdot 9 \\
5 \cdot 2 \\
5 \cdot 1\end{array}$ & 3,400 & $\begin{array}{l}1 \cdot 64 \\
1 \cdot 39 \\
1 \cdot 18\end{array}$ & $\begin{array}{l}1 \cdot 64 \\
1 \cdot 35 \\
1 \cdot 21\end{array}$ & $\begin{array}{l}\text { Fractured skull N } \\
\text { Coronary throm }\end{array}$ \\
\hline $\begin{array}{l}21 \\
21 \\
22\end{array}$ & $\begin{array}{l}64 \\
68 \\
53\end{array}$ & $\begin{array}{l}4 \cdot 7 \\
2 \cdot 8 \\
4 \cdot 5\end{array}$ & $\begin{array}{l}3,160 \\
2,560 \\
2,206\end{array}$ & $\begin{array}{l}1 \cdot 61 \\
2 \cdot 0 \\
1 \cdot 73\end{array}$ & $\begin{array}{l}1 \cdot 64 \\
2.04 \\
1 \cdot 73\end{array}$ & $\begin{array}{l}\text { Aortic stenosis } \\
\text { Carcinoma of cero }\end{array}$ \\
\hline 24 & 70 & $4 \cdot 5$ & 3,906 & $1 \cdot 82$ & $1 \cdot 82$ & $\begin{array}{c}\text { Coronary throm } \\
\text { bosis }\end{array}$ \\
\hline $\begin{array}{l}27 \\
27 \\
33\end{array}$ & $\begin{array}{l}54 \\
56 \\
44\end{array}$ & $\begin{array}{l}3 \cdot 6 \\
2 \cdot 8\end{array}$ & $\begin{array}{l}3,135 \\
2,785 \\
3,510\end{array}$ & $\begin{array}{l}1.85 \\
1.79\end{array}$ & $\begin{array}{l}1.79 \\
1.73 \\
1.61\end{array}$ & 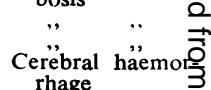 \\
\hline 48 & 50 & $6 \cdot 2$ & 2,610 & 1.54 & $1 \cdot 54$ & $\begin{array}{c}\text { Coronary throm } \\
\text { bosis }\end{array}$ \\
\hline $\begin{array}{l}48 \\
49 \\
50\end{array}$ & $\begin{array}{l}61 \\
50 \\
44\end{array}$ & $6 \cdot 0$ & $\begin{array}{l}1,470 \\
3,324\end{array}$ & $1 \cdot 54$ & $\begin{array}{l}1.47 \\
1.70 \\
1.49\end{array}$ & $\begin{array}{l}\text { Rheumatic " heart } \\
\text { disease, bilatera } \\
\text { hydrothorax }\end{array}$ \\
\hline 72 & 27 & 4.7 & & $1 \cdot 32$ & $1 \cdot 32$ & $\begin{array}{l}\text { Coronary thromp } \\
\text { bosis }\end{array}$ \\
\hline $\begin{array}{l}72 \\
72 \\
72 \\
72\end{array}$ & $\begin{array}{l}46 \\
60 \\
64 \\
70\end{array}$ & $\begin{array}{l}4 \cdot 0 \\
3 \cdot 0 \\
3 \cdot 7 \\
4 \cdot 7\end{array}$ & $\begin{array}{l}3,935 \\
2,300 \\
2,835\end{array}$ & $\begin{array}{l}1.49 \\
1.82 \\
2 \cdot 18 \\
1.76\end{array}$ & $\begin{array}{l}1 \cdot 49 \\
1 \cdot 76 \\
2 \cdot 18 \\
1 \cdot 79\end{array}$ & $\begin{array}{ll}\because . & , . \\
\ddot{.} & , . \\
. . & . .\end{array}$ \\
\hline $\begin{array}{l}6^{1} \\
24 \\
48 \\
48 \\
72\end{array}$ & & $\begin{array}{l}4 \cdot 0 \\
5 \cdot 0 \\
5.9 \\
5 \cdot 0 \\
7 \cdot 0 \\
4 \cdot 2 \\
4 \cdot 6 \\
7 \cdot 0\end{array}$ & $\begin{array}{l}960 \\
385\end{array}$ & $\begin{array}{l}1 \cdot 09 \\
1.08 \\
1 \cdot 12 \\
1 \cdot 10 \\
1 \cdot 12 \\
1.13 \\
1 \cdot 31 \\
1 \cdot 12\end{array}$ & $\begin{array}{l}1 \cdot 09 \\
1.11 \\
1 \cdot 14 \\
1 \cdot 10 \\
1 \cdot 20 \\
1 \cdot 13 \\
1.31 \\
1 \cdot 20\end{array}$ & 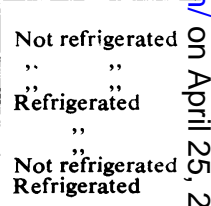 \\
\hline & & & & $r=0.62$ & $r=0.685$ & a \\
\hline
\end{tabular}

could clearly be affected by changes in the resise tance to the flow of air in the bronchial tree. Thळ use of hydrogen in demonstrating increased ain resistance is best illustrated by an experiment witణ a model lung consisting of a rubber bag, the ap resistance being increased by constricting the neck of the bag. The bag was ventilated at the two standard rates of 3 and 15 per minute with and without added resistance with air and then with 
$95 \%$ hydrogen. It can be seen from the tracing shown in Fig. 4 that with no added resistance the "tidal airs" were the same with air and hydrogen, the index of viscous resistance being 1.1. When the bag with added resistance was ventilated with air the "tidal air" at 3 per minute was three times that at 15 per minute, giving a viscous resistance index of 3.0. With hydrogen there was much less difference between the tidal airs at the two rates and the index of viscous resistance was 1.9 .

The experiment shown in Fig. 4 was repeated with different resistances to airflow in the neck of the bag, and from the results it was clear that the reduction in the

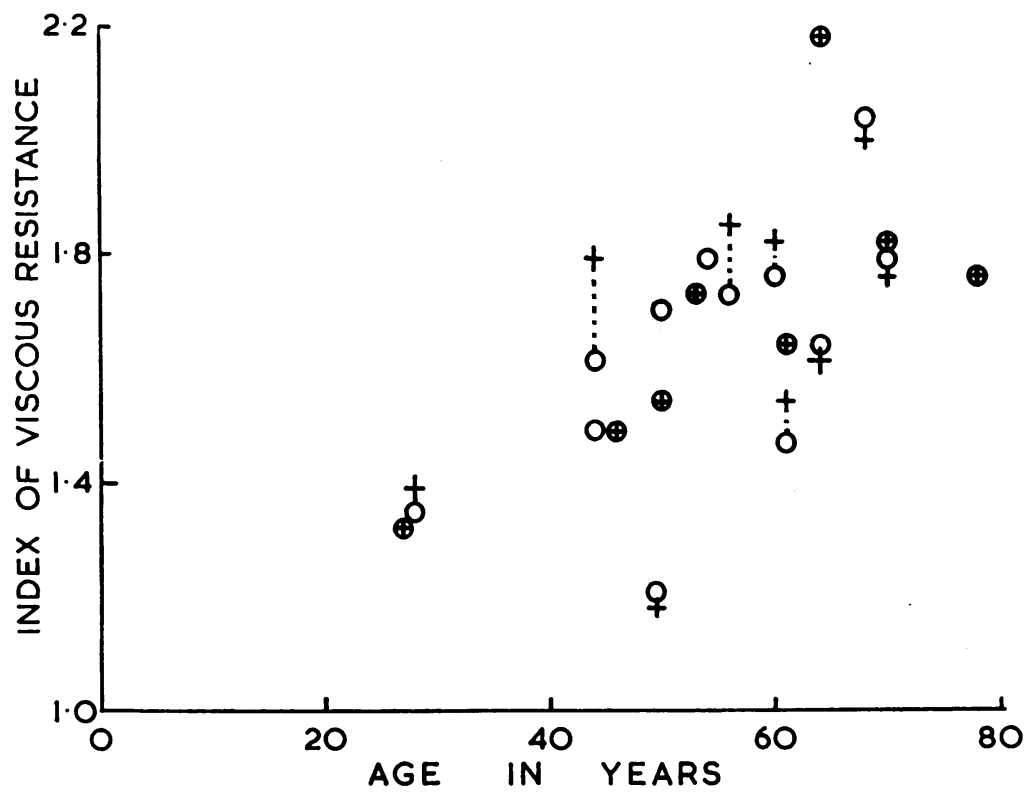
index of viscous resistance

with hydrogen was proportional to the resistance added. In each case it was possible to predict the index of viscous resistance with hydrogen from the formula:

$$
\mathrm{I}_{\mathrm{H}}=\left(\mathrm{I}_{\mathrm{A}}+1\right) \mathrm{V}_{\mathbf{H}}
$$

where $\mathrm{I}_{\mathrm{H}}=$ index of viscous resistance with hydrogen, $\mathrm{I}_{\mathbf{A}}=$ index of viscous resistance with air, $\mathrm{V}_{\mathbf{A}}=$ viscosity of air in micropoises, and $\mathrm{V}_{\mathrm{H}}=$ viscosity of hydrogen-air mixture in micropoises.
Experiments with hydrogen were carried out with five human lungs and results are shown in Table III. In three normal patients with no bronchial obstruction the index of viscous resistance showed little or no improvement with hydrogen. In two patients with bronchial obstruction due to blood or mucus in the air passages the index of viscous resistance with air was raised and the value with hydrogen agreed with the value predicted from the formula (Table III), and this is

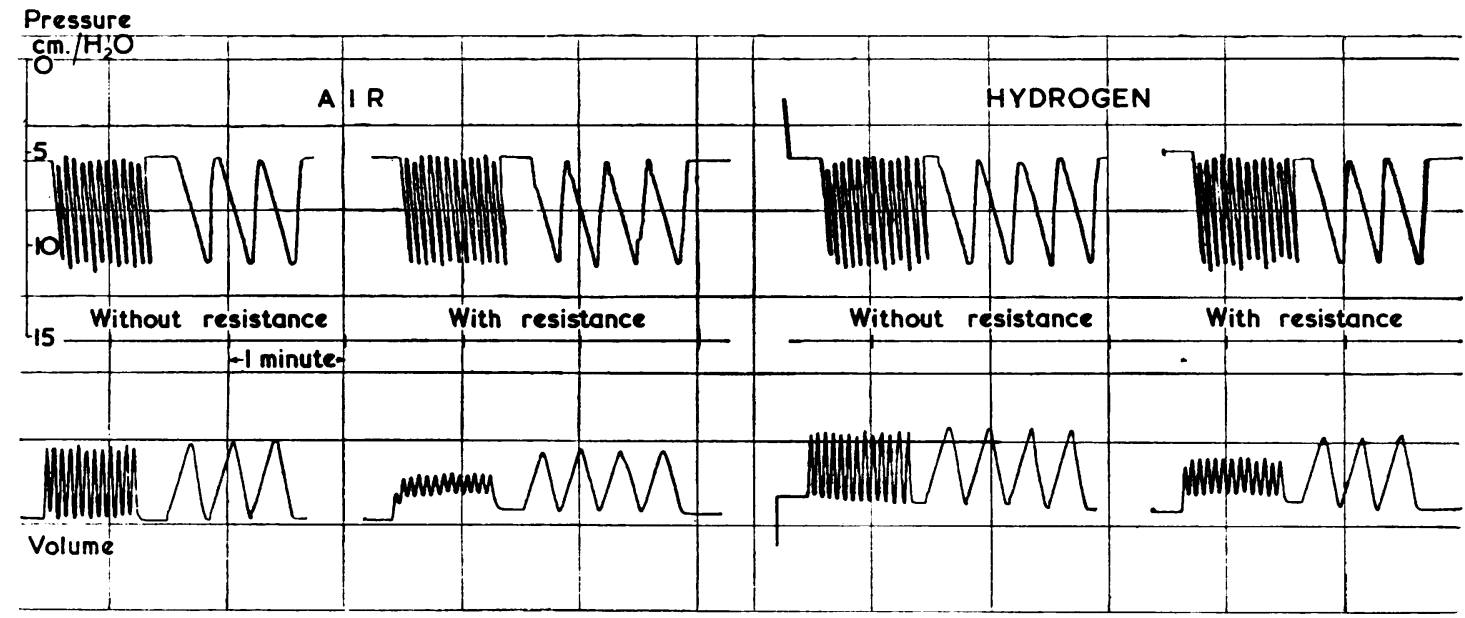

FIG. 4.-Ventilation of model lung in plethysmograph with and without added resistance, with air and with $95 \%$ hydrogen. With added resistance the index of viscous resistance is greater on air. 
TABLE III

INDEX OF VISCOUS RESISTANCE IN NORMAL HUMAN LUNGS AND LUNGS WITH BRONCHIAL OBSTRUCTION VENTILATED WITH AIR AND HYDROGEN

\begin{tabular}{|c|c|c|c|c|c|c|c|c|}
\hline \multirow{3}{*}{$\begin{array}{c}\text { Age } \\
\text { (Years) }\end{array}$} & \multirow{3}{*}{$\begin{array}{l}\mathbf{H}_{2} \\
\text { Concen- } \\
\text { tration } \\
(\%)\end{array}$} & \multicolumn{3}{|c|}{$\begin{array}{l}\text { Index of Viscous Resistance at } \\
\text { Corrected Level }\end{array}$} & \multicolumn{3}{|c|}{$\begin{array}{c}\text { Index of Viscous Resistance at } \\
\qquad-4 \mathrm{~cm} . \mathrm{H}_{2} \mathrm{O}\end{array}$} & \multirow{3}{*}{$\begin{array}{l}\text { Diagnosis } \\
\text { and Remarks }\end{array}$} \\
\hline & & \multirow{2}{*}{ Air } & \multicolumn{2}{|c|}{ Hydrogen } & \multirow{2}{*}{ Air } & \multicolumn{2}{|c|}{ Hydrogen } & \\
\hline & & & Predicted & Observed & & Predicted & Observed & \\
\hline 25 & 96 & $2 \cdot 86$ & $1 \cdot 92$ & 1.96 & & & & Fractured skull; bronchial obstruc \\
\hline $\begin{array}{l}44 \\
49 \\
55\end{array}$ & $\begin{array}{l}87 \\
92 \\
88\end{array}$ & $1 \cdot 41$ & $1 \cdot 32$ & $1 \cdot 32$ & $\begin{array}{l}1 \cdot 37 \\
1 \cdot 22 \\
3 \cdot 45\end{array}$ & $\begin{array}{l}1 \cdot 29 \\
1 \cdot 15 \\
2 \cdot 40\end{array}$ & $\begin{array}{l}1 \cdot 27 \\
1 \cdot 20 \\
2 \cdot 13\end{array}$ & $\begin{array}{l}\text { Cerebral haemorrhage } \\
\text { Coronary thrombosis } \\
\text { Coronary thrombosis ; bronchia } \\
\text { obstruction due to inhaled vomit }\end{array}$ \\
\hline 64 & 95 & $1 \cdot 85$ & $1 \cdot 43$ & $1 \cdot 7$ & $1 \cdot 85$ & $1 \cdot 43$ & $1 \cdot 7$ & Coronary thrombosis \\
\hline
\end{tabular}

taken to mean that the increase in viscous resistance was due wholly to bronchial obstruction.

\section{Discussion}

These experiments show that under controlled conditions normal lungs can conform to the definition of elasticity when ventilated in a plethysmograph up to 72 hours after death. If a constant negative pressure swing of the same magnitude as that found in life is applied to the lungs at a constant rate, a constant tidal air results. The lungs recoil to the same volume after each breath and show no tendency to over-stretch. This type of behaviour has not previously been demonstrated in human lungs removed at necropsy, and suggests that this method of investigating the properties of dead lungs may be useful in the study of lung elasticity.

No constant value for the distensibility of the lungs could be obtained in these experiments because the response of the lungs depended on the previous history of inflation or deflation as shown in the previous paper. In general the distensibility was of the same order as that found during life.

The most significant finding in this work is that the response of the lungs to a change in pressure as measured by the index of viscous resistance is slower in old normal than in young normal lungs. Experiments with hydrogen show that in normal lungs, with no demonstrable bronchial obstruction, this increase in viscous resistance is not produced in the bronchial tree, for the improvement with hydrogen is small. The increased resistance is produced in the lung tissue, and its gradual increase with age is in keeping with the impairment of respiratory function shown by reduction in maximum breathing capacity and mixing efficiency in older age groups.

The response of the lungs to ventilation has in the past been interpreted on the basis of laws of elasticity which do not necessarily apply to a visco- elastic system. The purely elastic response of the $\stackrel{\supset}{\supset}$ lungs can only be studied in static experiments ing which the viscous element is eliminated by allowing time for equilibrium to be reached. Such $\stackrel{\mathbb{3}}{3}$ experiments are difficult to carry out during life and have proved unsatisfactory with lungs studied in the plethysmograph.

As the lungs normally have to respond to rela- ? tively rapid changes in pressure, it is important to reconsider the phenomenon of loss of elasticity in the light of visco-elastic behaviour.

In a visco-elastic system loss of elasticity may be either relative, due to an increase in the viscous $\stackrel{\mathbb{Q}}{\varrho}$ element, or absolute, due to a decrease in the elastic $\overrightarrow{\vec{A}}$ element. An absolute loss of elasticity of the lungs $\frac{3}{3}$ would lead to an increase in distensibility, so that the volume change produced by a given pressure would increase. When the stage of complete loss of elasticity was reached there would be no elastic 으 recoil and the volume of the system would increase $\underset{\times}{\stackrel{\otimes}{x}}$ until limited by the size of the thorax. A relative $\frac{\sigma}{3}$ loss of elasticity would entail an increase in the time taken for the lungs to respond to a change $\delta$ in pressure on inflation and recoil so that each $₹$ phase of respiration would be cut short before 을 equilibrium was reached. When loss of elasticity $>$ is considered in this way it is possible to visualize varying degrees of elasticity which should not exist $\overline{\mathrm{N}}$ under the strict laws of classical elasticity. Further-or more, this explanation of loss of lung elasticity 0 makes the interpretation of our results clearer, for it suggests that the increase in tissue viscous resis- 0 tance observed with advancing age represents $a_{0}$ relative loss of elasticity in a visco-elastic lung due $\frac{\bar{\Phi}}{\Phi}$ primarily to increase in viscous resistance.

\section{SUMMARY}

The visco-elastic properties of human and $\cong$ animal lungs have been studied on ventilation in $\stackrel{\AA}{\varrho}$ a plethysmograph with a constant negative pres- $\overline{2}$ sure swing comparable to that found during life. 
An arbitrary index of the viscous resistance involved in ventilation has been devised from measurements of the difference in distensibility of the lungs at different respiration rates.

The index of viscous resistance measured in 20 normal human lungs increased with the age of the patient.

Comparison of the index of viscous resistance on air with that on hydrogen shows that the increase in viscous resistance demonstrated in normal lungs is not primarily due to bronchial obstruction.

It is suggested that what has in the past been termed "loss of pulmonary elasticity" may represent a relative loss of elasticity due to an increase in the viscous element of the visco-elastic response of the lungs.

REFERENCES

Bayliss, L. E., and Robertson, G. W. (1939). Quart. J. exp. Physiol., $29,27$.

Dean, R. B., and Visscher, M. B. (1941). Amer. J. Physiol., 134, 450 McIlroy, M. B. (1952). Thorax, 7, 285.

\title{
A POST-MORTEM STUDY OF THE VISCO-ELASTIC PROPERTIES OF THE LUNGS IN EMPHYSEMA
}

\author{
BY \\ M. B. McIlROY AND R. V. CHRISTIE \\ From the Medical Professorial Unit, St. Bartholomew's Hospital, London
}

(RECEIVED FOR PUBLICATION OCTOBER 6, 1952)

It has been shown in the previous paper that the visco-elastic response of isolated lungs to ventilation can be studied in a plethysmograph. In this paper the behaviour of lungs from patients with emphysema has been studied in the plethysmograph in the same way.

\section{Methods}

The lungs were removed at necropsy as already described, and after inflation to open up collapsed alveoli and restore the lung volume to about that found during life, the lungs were ventilated in the plethysmograph by means of a hand pump. The arbitrary index of viscous resistance was measured in each case by comparing the response of the lungs to ventilation at 3 and 15 respirations per minute. In some cases the lungs were ventilated with hydrogen as well as air to assess the degree of bronchial obstruction.

The lung volume and mixing efficiency were measured before and after death in a number of patients. At the end of each experiment the lungs were fixed by pouring formalin down the trachea and examined macroscopically to assess the amount of debris in the bronchial tree. Large sections of the lungs were prepared by the technique of Gough, James, and Wentworth (1949) and representative areas of each lung were also examined microscopically.

\section{RESUlts}

Ten patients with emphysema were investigated between four and a half and 96 hours after death and clinical details of the cases are given in an appendix. Results are shown in Table I. The elastic recoil of the lungs as measured by the pressure generated in the obstructed trachea on opening the thorax varied between 0 and $3.2 \mathrm{~cm}$. $\mathrm{H}_{2} \mathrm{O}$ with a mean of $1.75 \mathrm{~cm} . \mathrm{H}_{2} \mathrm{O}$. These figures are smaller than those found in normal lungs ( 2.8 to $6.2 \mathrm{~cm}$. $\mathrm{H}_{2} \mathrm{O}$, mean $4.3 \mathrm{~cm} . \mathrm{H}_{2} \mathrm{O}$ ).

The lung volume and mixing efficiency were measured before and after death in six cases and in general there was moderately good agreement between ante-mortem and post-mortem measurements. The mixing efficiency during life was reduced in all cases and the figures after death were similarly reduced (Table I).

The "index of viscous resistance" was markedly increased in all patients, the range of values being 3.12 to 5.55 compared with the normal range of 1.18 to 2.18. This increase was found both at the arbitrary plethysmograph pressure of $-4 \mathrm{~cm}$. $\mathrm{H}_{2} \mathrm{O}$ and at the corrected level for each case. A typical tracing of the ventilation of emphysematous lungs at 3 and 15 respirations per minute is shown in Fig. 1. This shows that in emphysema the lungs respond to a constant pressure swing with a constant tidal air in the same way as normal lungs, and also illustrates the marked reduction in tidal air with more rapid breathing.

The results of experiments with hydrogen in four cases are shown in Table II. In each case 